\title{
Hvad blev der af den klassiske Kold Krigs-aktivisme? Den nordiske dimension i dansk udenrigspolitik
}

\author{
Mikkel Runge Olesen ${ }^{1}$ \\ Postdoc, Dansk Institut for Internationale Studier
}

\author{
Anders Wivel \\ Professor MSO, Institut for Statskundskab, Københavns Universitet
}

Siden den Kolde Krigs afslutning har dansk udenrigspolitisk aktivisme været præget af dansk militært engagement sammen med USA. Aktivismens aktuelle udtryk er imidlertid ikke i modstrid til klassisk nordisk aktivisme. Snarere er der tale om nordisk aktivisme med andre midler. Den danske omstilling fik ikke straks tilslutning fra de øvrige nordiske hovedstæder, men en udvikling i den retning synes nu på vej. Dansk aktivisme og nordisk aktivisme kan hermed måske igen snart blive synonymer.

Både den nordiske selvbevidsthed og omverdenens begejstring var til at tage og føle på, da John F. Kennedy Center for the Performing Arts i Washington DC, et af USA's største kulturcentre, i en hel måned og med besøg af 700 nordiske kunstnere satte fokus på såkaldt Nordic cool i begyndelsen af 2013. András Simonyi fra John Hopkins University Center for Transatlantic Relations opsummerede begejstringen 'Using a smart mindset on power, the Nordics show that both soft and hard power capacities, part of one power toolbox, are the critical components that comprise a nation's global brand [...] Together they are a formidable little giant to be reckoned with both economically, culturally and militarily' (Simonyi 2013).

Festivalen var dog hverken så usædvanlig eller så indflydelsesrig som nyhedsdækningen i de nordiske lande kunne give indtryk af. Kennedy Center afholder mange festivaler hvert år og har både før og efter den nordiske festival sat fokus på regioner og lande, og mens den nordiske festival trak 200.000 besøgende til sine arrangementer, så trak en lignende festival med fokus på indisk kunst og kultur to år tidligere 400.000. Til gengæld satte festivalen fokus på en række karakteristika, der passede fint med en traditionel opfattelse af de nordiske lande og deres rolle i international politik: de nordiske lande udgør et fællesskab, dette fællesskab har en række særlige karakteristika, disse karakteristika har gjort Norden til en succes, andre lande kan på den baggrund med fordel lære af Norden, og Norden er villig til at lære fra sig.

Mens den nordiske aktivisme har opnået betydelig politisk og forskningsmæssig opmærksomhed (Browning 2007; Dahl and Järvenpää 2014; Ingebritsen 2002; Schouenborg 2013a; Grøn et al. 2015), så synes den nordiske dimension kun at spille en marginal rolle i den aktivisme, som har karakteriseret dansk udenrigspolitik gennem de seneste årtier. ${ }^{2}$ På flere områder synes den danske aktivisme ligefrem i kontrast til den nordiske. Den nordiske aktivismes metode er det diplomatiske arbejde i internationale institutioner, men et væsentligt kendetegn ved den danske aktivisme er et stærkt militært engagement, ofte i samarbejde med verdens stærkeste militærmagt USA. Den nordiske aktivismes indhold har været karakteriseret ved målsætninger om en styrkelse af det internationale samfund, afspænding og øget global lighed, men den danske aktivisme betyder deltagelse i militære konflikter uden det internationale samfunds velsignelse og har været ledsaget af begrænsninger i den danske udviklingsbistand. Endelig er den nordiske aktivisme netop nordisk i den forstand, at den eksplicit udtrykker et fællesnordisk værdigrundlag, mens den danske aktivisme er blevet formuleret som en europæisk og især atlantisk indlejring af udenrigspolitikken, ikke en nordisk.

Et ensidigt fokus på disse umiddelbare forskelle risikerer dog at give et fordrejet billede af relationen mellem 
dansk og nordisk aktivisme. Der er ikke tale om et enten/ eller men derimod om en historisk betinget relation under stadig udvikling og påvirkning af mødet mellem det danske, det nordiske og forandringer i de geopolitiske betingelser for udenrigspolitikken. Vi argumenter på den baggrund for, at dansk udenrigspolitisk aktivisme snarere end en modsætning til den nordiske aktivisme kan forstås som indlejret i nordisk aktivisme, og at dansk aktivisme på den baggrund repræsenterer en variant af den nordiske aktivisme snarere end en kontrast til denne særlige type aktivisme. På den baggrund er den nordiske dimension et væsentligt og underbelyst element i forståelsen af den danske aktivismes oprindelse og aktuelle udtryk. Vores argument falder i fire dele. Først identificerer vi den nordiske aktivismes karakteristika. Dernæst analyserer vi på den baggrund udviklingen af dansk udenrigspolitisk aktivisme først under og dernæst efter den Kolde Krig og viser, hvordan den danske aktivisme både er indlejret i den nordiske aktivisme og repræsenterer en videreudvikling af denne. I artiklens sidste afsnit spørger vi på den baggrund, hvilken fremtidig rolle vi forventer at den nordiske dimension vil spille i dansk udenrigspolitisk aktivisme, hvorefter artiklen konkluderes.

\section{Hvad er nordisk aktivisme?}

Den nordiske aktivisme kan defineres med udgangspunkt i både formål, metode og indhold. Formålet med den nordiske er aktivt at påvirke udviklingen af det internationale samfunds normer og værdier gennem aktiv deltagelse. I den forstand synes den nordiske aktivisme mere konsistent med stormagternes klassiske offensive rolle som regelmagere og producenter af international orden end med småstaternes klassiske defensive rolle som 'regeltagere' og forbrugere af den orden, som stormagterne har skabt (Hey 2003; Neumann og Gstöhl 2006).

De nordiske landes aktive politik for at få indflydelse på den internationale dagsorden adskiller sig imidlertid markant fra traditionel stormagtspolitik. Mens ambitionen har været en stormagt værdig, så har metoden til at opnå disse formål været diplomati og overtalelse gennem argumenters og eksemplets magt, typiske småstatsstrategier, som står i kontrast til stormagterne, der typisk har forfulgt deres politiske mål gennem anvendelse af eller trussel om anvendelse af hård magt (Keohane 1969). De nordiske lande har i særlig grad operationaliseret deres 'overtalelsesstrategi' som norm-entreprenører, der forfølger deres mål gennem diplomatisk arbejde for at underbygge de internationale normer, som man ønsker bevaret, og ændre de internationale normer, som man vurderer som inkonsistente med egne værdier (Ingebritsen 2002; Jakobsen 2009). At være norm-entreprenør indebærer både en identifikation af de 'rigtige' normer og at bidrage aktivt til at fremme og underbygge disse ved at præsentere løsninger på internationale udfordringer, ligesom der ofte indgår et element af benchmarking: '[i]f the advocate also acts as a forerunner and complies with the norms it propagates, i.e. "practicing what you preach", the advocacy becomes more convincing' (Björkdahl 2008: 137). En konsekvens af denne strategi har været, at indflydelsesmaksimering og branding af den nordiske model ofte er blevet set som to sider af den samme sag: jo bedre forståelse omverdenen havde for den nordiske model, jo bedre forståelse ville de have for de internationale løsninger, som blev forsøgt fremmet af de nordiske lande (Browning 2007). Samtidig var formen for den nordiske indflydelsesmaksimering også tæt knyttet til disse samfunds grundlæggende værdier, idet et væsentligt middel til indflydelse var uformelle kontakter og forhandlinger rundet af de nordiske landes lighedsideologi og lave magtdistance (Grøn et al. 2015; Panke 2010).

Det er på den baggrund ikke overraskende, at den nordiske aktivismes indhold i høj grad korresponderer med de grundlæggende værdier i den nordiske velfærdsstat (Schouenborg 2013a). Mest grundlæggende er udgangspunktet i en universalistisk solidaritetsopfattelse, som indadtil gav borgerne en række sociale rettigheder, som på nordisk niveau betød en konvention om social tryghed fra 1955, der sikrede nordiske borgere en række rettigheder uanset, hvor i regionen de valgte at bosætte sig, og som på europæisk og globalt niveau førte til et fokus på styrkelse af det internationale samfunds og dets institutioner, international lighed og fredelig konfliktløsning. Disse værdier er traditionelt kommet til udtryk i landenes udenrigspolitik som stærk støtte til og aktiv anvendelse af FN systemet, store bidrag til udviklingsbistand og fredsbevarende styrker, og de kommer i dag til udtryk i nordisk samarbejde på områder som klima og miljø, udviklingsbistand, menneskerettigheder, international ret, FN, fredsopbygning, handel og køn (Schouenborg 2013b).

Mens værdierne er centrale for den nordiske aktivisme, så problematiserer de også i hvor høj grad aktivismen er 'nordisk'. Dels er værdierne snarere skandinaviske end nordiske. Det var i Danmark, Norge og Sverige, at store kompromiser mellem arbejdsgivere og arbejdstagere i 1930erne kom til at danne baggrund for udviklingen af velfærdsstater, der både var baseret på og kom til at udtrykke og dermed understøtte disse værdier, mens Finland og Island først senere udviklede velfærdsstater og i en form, som adskilte sig mindre fra resten af Europa end i de skandinaviske lande. Den nordiske aktivisme var således primært en skandinavisk aktivisme, som gradvist blev adopteret af Island og Finland. For Island skete dette, da landet, særligt efter den Kolde Krigs ophør, begyndte at 
spille en mere aktiv international rolle. Og for Finland begyndte dette allerede under Den Kolde Krig. Her spillede Finland en aktiv rolle i Konferencen om Sikkerhed og Samarbejde i Europa (CSCE) og i Helsinki-aftalerne, som ved at etablere en række fælles principper for sameksistensen mellem de to blokkes medlemmer, kom til at udgøre en væsentlig del af grundlaget for samarbejde mellem Øst og Vest frem til den Kolde Krigs afslutning. Dels synes nogle af indholdstrækkene ved den nordiske model at være knyttet til de nordiske landes småstatsstatus snarere end deres fælles nordiske udgangspunkt. Det gælder primært indsatsen for at styrke det internationale samfund gennem institutionel indbinding af stormagterne, der er et fællestræk ved de europæiske småstaters udenrigspolitik fra Anden Verdenskrig og frem (Wallace 1999), og sekundært indsatsen for international afspænding og nedrustning, der ligeledes er blevet forfulgt af en række mindre lande (Goetschel 2013). Den nordiske aktivisme er således ikke et alternativ til den måde, som mange andre europæiske småstater fører udenrigspolitik på, men snarere en tidligere udviklet og mere udbygget aktivisme.

\section{Nordisk med forbehold: Danmark og den nordiske aktivismes gyldne år}

Dansk udenrigspolitik efter Anden Verdenskrig kan bedst karakteriseres som nordisk med forbehold. Politikken var karakteriseret ved balancen mellem en tilpasning til den Kolde Krigs trusselsbillede og en nordisk indlejret udenrigspolitisk aktivisme. Mellemkrigstiden havde set de første spæde skridt i retning af dansk udenrigspolitisk aktivisme i form af P. Munchs engagement i Folkeforbundet samt en mere målrettet forfølgelse af de handelspolitiske interesser og dermed taget de første skridt væk fra den reaktive tilpasningspolitik, der havde præget udenrigspolitikken fra nederlaget til Preussen og Østrig i $1864 \mathrm{og}$ frem til Første Verdenskrigs afslutning. Grundlaget for dette skift var ikke udelukkende idealistisk, men byggede også på opfattelsen af, at det generelt måtte være i en småstats langsigtede interesse at arbejde for, at det internationale system blev mere præget af regler og mindre af rå magtpolitik (Branner 2000: 339). Da spændingen i Europa øgedes sidst i 1940erne, ikke mindst efter kuppet i Tjekkoslovakiet i februar 1948, undersøgte Danmark sammen med Sverige og Norge mulighederne for et skandinavisk forsvarsforbund i 1948-49. Imidlertid insisterede Sverige på, at forbundet skulle være neutralt i konflikten mellem østblok og vestblok, samtidig med, at Danmark og Norge blev inviteret til at deltage i det vestlige forsvarssamarbejde, og USA understregede, at et nordisk forsvarsfund ikke kunne regne med militær assistance fra USA og deres allierede. På den baggrund valgte Danmark og Norge, sammen med Island, at tilslutte sig NATO, mens Sverige, sammen med Finland, valgte neutraliteten.

Den sikkerhedspolitiske deling af Norden var dog ikke et farvel til den nordiske dimension i dansk udenrigspolitik, men snarere et vilkår, som kom til at påvirke den danske aktivismes udtryk og udvikling. Allerede i 1951 tog Danmark initiativ til oprettelsen af Nordisk Råd, og den nordiske dimension kom sammen med Europa, NATO og FN til at udgøre de fire søjler i udenrigspolitikken (Hækkerup 1965). Umiddelbart kunne det synes som om NATO-søjlen, der var den afgørende for muligheden for at forsvare det danske territorium og dermed Danmarks overlevelse som selvstændig stat i tilfælde af et militært angreb, og den europæiske søjle, der primært handlede om adgang til de vigtige eksportmarkeder i Storbritannien og Tyskland, var de bærende søjler i den danske udenrigspolitik, mens den nordiske søjle og FN-søjlen i højere grad var til pynt. Ganske vist fremhævede både politikere og forskere den særlige 'spindelvævsintegration' mellem de nordiske lande - ofte understøttet af samarbejdet i Nordisk Råd - og typisk med afsæt i de nordiske landes fællestræk (Andrén 1967), men disse samarbejder var 'low politics' og både forsøget på at skabe et forsvarsforbund og det senere forsøg på at skabe et nordisk fællesmarked i 1967-1970 mislykkedes. Ganske vist smeltede den nordiske søjle næsten sammen med FN-søjlen i værdipolitikken, hvor de nordiske lande ofte blev set som en samlet blok af lande, der arbejdede for afspænding og øget global lighed, men den værdipolitiske aktivisme var indlejret i et samarbejde, hvor Sverige tog et lederskab, der ofte var mere dristigt og præsenterede et klarere alternativ til supermagternes dagsorden end den danske politik, der mestendels afstod fra positioner, som kunne tolkes som direkte kritik af supermagterne. Indenfor NATO formåede Danmark og Norge dog ligeledes at føre en vis værdikamp for alliancens normative status som en alliance af demokratier. Det skete blandt andet i de to landes fælles modstand imod NATO's planer i 1950erne om at inkludere diktaturstaterne Portugal, Grækenland, Tyrkiet og, vigtigst af alt, Spanien i alliancen. Hvad angår de tre første lande, viste denne kamp sig uoverkommelig, men hvad angik det fascistiske Spanien, formåede dansk-norsk pres faktisk at bremse landets aspirationer om NATOmedlemskab. Om end disse bestræbelser næppe kunne have båret frugt, hvis ikke USA havde kunnet sikre sine militære interesser i Spanien gennem bilaterale aftaler, så vidner episoden dog om, at de nordiske NATO-medlemmers status som norm-entreprenører gjorde det vanskeligt at overhøre dem i den slags sager (Villaume 1995: 67686). Endeligt førte Danmark, særligt fra 1960erne, med dét udgangspunkt en aktivistisk værdipolitik gennem 
bistandspolitikken og afspændingspolitikken, særligt i FN, der med Petersens ord gav lejlighed til 'at projicere et image af os selv som en fredelig velmenende nation, præget af „de gode viljer““ (Petersen 1983: 76).

Det kunne på den baggrund være fristende at konkludere, at dansk udenrigspolitik i denne periode var nordisk i idealpolitikken, mens den var atlantisk (sikkerhed) og europæisk (økonomi) i realpolitikken, men det ville være forkert. Idealpolitikken var et væsentligt element i realpolitikken på mindst tre måder. For det første rummede det nordiske samarbejde væsentlige elementer, der nærmede sig, eller reelt udgjorde, 'high politics', ikke mindst fordi de nordiske NATO-lande ikke altid undgik at lægge sig ud med deres NATO-allierede. Det gjorde sig særligt gældende i de nordiske landes førnævnte bestræbelser for afspænding - særligt i den Kolde Krigs sene periode. Her begyndte den gradvist voksende nordiske entusiasme i løbet af 1980erne om politiske emner som eksempelvis Norden som kernevåbenfri zone i stigende grad at stå i modstrid til NATO-linjen og USA (Petersen 2004: 322-323). Afspænding var også udgangspunktet, da den danske regering, til amerikanernes store irritation, under påbud fra det såkaldte alternative sikkerhedspolitiske flertal i Folketinget, indførte fodnoter i NATO-dokumenter om missilopstilling i Centraleuropa (Petersen 2004: 282311, 329-360).

For det andet spillede Norden en væsentlig rolle i Danmarks geopolitiske positionering i den Kolde Krig gennem begreber som det nordiske sikkerhedsfællesskab og den nordiske balance. Ifølge modellen om den nordiske balance havde den Kolde Krig delt Norden i tre kategorier: NATO-lande, der opfyldte minimumsbestemmelser for medlemskab, det neutrale og militært stærke Sverige, og endelig det semineutrale Finland i venskabspagt med Sovjet. Ud fra tanken om, at denne status quo var nogenlunde acceptabel for begge supermagter, gav den nordiske balance de nordiske lande mulighed for at justere deres forhold til en af supermagterne som modtræk til, at den anden supermagt evt. søgte at udvide sin interessesfære i Norden (Brundtland 1967). Det medvirkede til at skabe et for en småstat usædvanligt stort udenrigspolitisk handlerum for Danmark (og Norge).

Endelig spillede ideen om Norden en væsentlig rolle i legitimeringen af den aktivistiske udenrigspolitik. Tanken om øget nordisk samarbejde af enhver form forblev ekstremt populær i den danske befolkning, selv efter beslutningen om NATO var taget (Gallup 1956). Særligt i den Kolde Krigs første år var man i København meget opmærksom på, hvilken linje man lagde i Oslo, når vanskelige beslutninger skulle tages (Olesen og Villaume 2005: 610). Den nordiske indlejring sikrede en bred folkelig opbakning, som understøttede den aktivistiske udenrigs- politiks demokratiske legitimitet og finansiering, og den understøttede dermed også politikkens kontinuitet. Det er også i denne henseende interessant at notere, at mens danskerne foretrak EF frem for en nordisk økonomisk union (Gallup 1969), så var opbakningen til de andre nordiske landes optag i EF i 1991 så stærk, at den generelle opbakning til EF i en sådan hypotetisk situation gik fra 57\% til 73\% (Gallup 1991). Dermed synes en situation med Danmark som brobygger imellem resten af Norden og Europa, i det mindste når det gælder den $ø$ konomiske politik, at have nydt stor opbakning.

Samtidig var dansk medlemskab af EU og NATO de mest håndfaste eksempler på, at Norden ikke formåede at være et ligeværdigt alternativ til de euro-atlantiske institutioner i spørgsmål om kerneinteresser som nationalt forsvar og økonomisk bæredygtighed. Det betød, at den nordiske aktivisme, selv i dens gyldne periode, var henvist til emnespecifik fokusering på udviklingsbistand og på mere eller mindre formaliseret samarbejde om enkeltsager, der til tider afprøvede grænsen for, hvad man kunne gøre og sige som loyalt NATO-medlem, men aldrig overskred denne grænse, når den nationale interesse stod på spil, og der ville kunne sættes spørgsmålstegn ved medlemskabet. Den nordiske aktivisme blev nok formuleret som et alternativ til stormagternes interessepolitik, men den var samtidig indlejret i de mest markante institutionelle udtryk for denne politik, EU og NATO. Pragmatisk interessepolitik og nordisk idealpolitik var ikke hinandens modsætninger. Tværtimod udgjorde pragmatismen grundlaget for idealpolitikken, der blev muliggjort af, at de grundlæggende interesser var sikret gennem den euroatlantiske indlejring. I den forstand var den nordiske aktivisme en 'luksusvare', som man kun kunne tillade sig, fordi USA og de europæiske stormagter havde en interesse i at producere 'basisvarer' som stabilitet og sikkerhed (Wivel 2014). Som påpeget af en af periodens mest markante udenrigsministre Per Hækkerup, så var dette i de politiske beslutningstageres optik hverken udtryk for en hyklerisk, usammenhængende eller modsætningsfyldt politik: 'Idealisme og realisme er ikke modstående begreber [...] Derimod går idealisme og realisme særdeles vel i spand. Ja, ret beset må virkelig idealisme parres med realisme, for kun en realistisk erkendelse af virkelighed og muligheder giver det bedste resultat for en bestemt idealistisk stræben' (Hækkerup 1965: 15).

\section{Fra ikke-nordisk til anti-nordisk? Dansk uden- rigspolitik aktivisme efter den Kolde Krig}

Dansk udenrigspolitisk aktivisme efter den Kolde Krig rummer på én gang en eksplicit afstandtagen fra det nordiske, og en videreførelse og endda accentuering af de nordiske kerneværdier i udenrigspolitikken. Under den 
Kolde Krig repræsenterede de nordiske lande anført af Sverige en tredje vej mellem østblok og vestblok, som de opfattede som både forskellig fra og bedre end stormagternes politik (Wæver 1992). Norden var en idealistisk og progressiv anti-tese til stormagternes interessepolitik (Browning 2007; Mouritzen 1995). Efter den Kolde Krigs afslutning forsvandt denne modsætningen for Danmarks vedkommende.

Aktivismen blev efter den Kolde Krig et definerende kendetegn ved dansk udenrigspolitik, hvor den nu både udtrykte en målsætning om aktiv tilstedeværelse og bidrag til international konfliktløsning og ordensskabelse - i Danmarks nærområde, i Europa og i stigende grad globalt - og samtidig angav en række diplomatiske, økonomiske, institutionelle og militære midler til dette, om end vægtningen af disse midler kom til at variere over tid og fik forskellige betegnelser som 'aktiv internationalisme', 'engageret internationalisme' og 'international aktivisme' (Pedersen 2012: 112). Målsætningen i dansk udenrigspolitik var fra begyndelsen af perioden at arbejde målrettet for en udbredelse af værdier som internationalt samarbejde, menneskerettigheder, afspænding og økologisk bæredygtighed, både regionalt og globalt (Holm 1997; Udenrigsministeriet 1990, 2003). Denne tilgang adskilte sig fra dansk udenrigspolitik under den Kolde Krig, hvor aktivismen blev betragtet som supplerende og langsigtet indenfor et snævert politisk rum defineret af den Kolde Krigs magtpolitik og Danmarks geopolitiske position indenfor denne (se eksempelvis Hækkerup 1965). Det betød også, at hvor aktivismen tidligere primært blev artikuleret fra en nordisk værdipolitisk platform, så blev platformen umiddelbart efter den Kolde Krigs afslutning europæisk og op gennem 1990erne - med de danske vælgeres nej til Traktaten om Den Europæiske Union i 1992 som et afgørende vendepunkt - stadig mere transatlantisk (Holm 2002), ikke mindst i sikkerhedspolitikken. Med amerikansk opbakning udfordrede de danske beslutningstagere den sovjetiske årtier-lange besættelse af de baltiske lande, sendte flådestøtte til amerikanerne i den første Golfkrig og tungt bevæbnede fredsbevarende styrker til Balkan (Petersen 2004: 451-465), hvilket senere blev fulgt op af bl.a. militært engagement i Irak og Afghanistan og rollen som en af de mest aktive deltagere i bombetogterne over Libyen i 2011. Et dansk tilbud om at støtte et amerikansk angreb på Syrien i eftersommeren 2013 blev dog gjort uaktuelt, da den amerikansk ledede koalition, fra starten plaget af uro, valgte at stille sig tilfreds, da Syriens regering udleverede sine kemiske våben. Endelig har vi senest set det danske bidrag i konflikten med Islamisk Stat fra 2014, først med et transportfly og sidenhen med kampfly. Det er sigende for aktivismens velbefindende, at støtten i det danske folketing forsat har været usædvanligt bred - beslutningen om transportflyet havde tilslutning fra et enigt folketing (FT 2014a), og beslutningen om kampflyene manglede kun støtte fra Enhedslisten (FT 2014b). Transformationen fra nordisk fredsdue og 'allieret med forbehold' til militært aktivistisk høg og 'super-atlantisk' partner med USA synes komplet (Se Villaume 1995; Mouritzen 2007; Pedersen 2012).

Dette understøttedes af, at Danmark efterhånden har udviklet en villighed til at handle udenom FN, hvis legitimitet i danske øjne blev svækket af dets manglende evne til at håndtere 1990ernes konflikter på Balkan. Resultatet blev at Danmark deltog i en militær operation i Kosovo i 1999 på trods af fraværet af FN-mandat. Det var et brud med en lang dansk nordisk kamp for netop at styrke FN's myndighed i krigs- og krisesituationer, men bruddet syntes mindre voldsomt, fordi ledende politikere kunne henvise til, at det var en ikke-idealistisk komponent i FN-systemets opbygning i form af den russiske vetoret i sikkerhedsrådet, der havde forhindret et FN-mandat (Helveg 1999). Hertil kom, at selve måden Danmark involverede sig i krigene på Balkan, var meget anderledes, end den havde været tidligere. Danmark havde før sendt fredsbevarende styrker til Cypern, men de havde været let bevæbnede og ikke involveret i egentlige krigshandlinger. På Balkan deltog Danmark derimod direkte i væbnede sammenstød med kampvogne og jagerfly (Rasmussen 2005), og i Irak og Afghanistan fremstod Danmark som en 'upåklagelig allieret', der altid var villig til at stille op og yde en aktiv indsats de farligste steder i verden, når NATO og USA vurderede, at der var behov (Ringsmose og Rynning 2008); en tilsyneladende stærk kontrast til den Kolde Krig, hvor USA-samarbejde og NATO-medlemskab blev betragtet som et nødvendigt onde, og forsvarsudgifter holdt på det, som de danske beslutningstagere vurderede som et minimumskontingent for fortsat medlemskab af alliancen (Ringsmose 2009).

Det betyder dog langtfra, at den danske aktivisme med sin vægt på det bilaterale forhold til enesupermagten og sit fokus på militære aktivisme som afgørende for forfølgelsen af de udenrigspolitiske ambitioner kan betragtes som antitesen til den traditionelle aktivisme. For det første er der en høj grad af kontinuitet i de udenrigspolitiske mål: internationalt samarbejde, menneskerettigheder, afspænding og økologisk bæredygtighed er netop konsistente med den nordiske aktivisme og dens spejling af velfærdsstatens værdier. Også når det gælder anvendelsen af militære midler er forskellen til fortiden blevet nedtonet af de danske udenrigspolitiske beslutningstagere, for hvem institutionel og militær aktivisme fremstår som to sider af den samme mønt: et aktivt bidrag til en stabil international orden baseret på et stærkt liberal-demokratisk værdifællesskab (Wivel 2005). For det andet blev den at- 
lantiske orientering i udenrigspolitikken et fremtrædende træk i dansk udenrigspolitik allerede efter Anden Verdenskrig. Ganske vist nedtonedes med aktivismens tætte samarbejde med USA den stormagtsskepsis, der fra 1864 og især siden P. Munchs udenrigspolitik i mellemkrigstiden havde spillet en afgørende rolle i Danmarks internationale positionering (Lidegaard 2003; Pedersen 1970), men kontrasten til den nordiske værdipolitik var mindre end, hvad den umiddelbart kunne synes. Danmark var også under den Kolde Krig - trods højt-profilerede forbehold eksempelvis når det gjaldt kernevåben på dansk territorium - velintegreret i den amerikanske interessesfære, og denne position nød opbakning fra en bred koalition af politiske partier, inklusive Socialdemokraterne. Samtidig ændrede USA's udenrigspolitik sig markant efter den Kolde Krig. Hvor forholdet til fjenden Sovjetunionen havde været definerende for amerikanske diplomatiske prioriteringer og militært engagement under den Kolde Krig, så gav den nye situation efter den Kolde Krig plads til en amerikansk udenrigspolitik med et stærkere fokus på at sprede liberal-demokratiske normer som demokrati og menneskerettigheder, der også blev delt af både den udenrigspolitiske elite og vælgerne i Danmark, og som havde klare paralleller til den nordiske aktivisme. Det samme kunne til dels siges om den fælles europæiske udenrigspolitik, som var under udvikling, og som når det gjaldt FN-politikken i nogen grad indarbejdede den tidligere distinkte nordiske position (Laatikainen 2003).

Endelig er det øgede fokus på militære midler i dansk udenrigspolitik et svar på en øget efterspørgsel efter denne type af bidrag i det internationale samfund (Wivel 2013: 311). Den Kolde krigs afslutning betød, at en lang række konflikter, der havde været undertrykt af supermagtskonflikten nu kom op til overfladen, og samtidig at det internationale samfund havde mulighed for at reagere militært på disse konflikter med fredsskabende foranstaltninger uden risiko for en altødelæggende supermagtskonflikt. På den baggrund var et centralt spørgsmål i 1990ernes NATO-debat med den amerikanske senator Richard Lugars ord om alliancen måtte „go out of area or out of business" og fredsskabelse var et mål allerede i EU's Petersberg-opgaver i 1992. Alene i perioden 1989 til 1994 autoriserede FN's Sikkerhedsråd 20 nye operationer, og antallet af fredsbevarende FN-tropper steg fra 11.000 til 75.000 (http://www.un.org/en/peacekeeping/ operations/surge.shtml). En væsentlig årsag til, at Danmark har kunnet imødekomme denne efterspørgsel, er en lang tradition for militært engagement med rødder i mellemkrigstiden og en væsentlig forøgelse under den Kolde Krig, hvor Danmark fra 1948 til 1989 med kun tre undtagelser bidrog til samtlige FN's missioner og gennem hele perioden kontinuerligt havde soldater udsendt
(Jakobsen 2015). Dette engagement var i kold krigs-perioden indlejret $\mathrm{i}$ en nordisk model for fredsbevarende operationer som omfattede jævnlige konsultationer mellem de nordiske forsvarsministre, arbejdsgrupper, uddannelse og evnen og viljen til at reagere hurtigt på henvendelser fra FN.

For dansk udenrigspolitik var der således ikke tale om et brud med den nordiske aktivisme, men snarere udviklingen af en ny variant under nye vilkår. Den nordiske koldkrigs-aktivisme var baseret på en række modstillingspar: 'FN vs. magtpolitik', 'diplomati vs. krig', 'Norden vs. supermagterne'. Med USA's og deres allieredes sejr i den Kolde Krig blev det hurtigt umuligt at opretholde disse modstillinger. FN var nu en arena for kampen om at definere rammerne for den nye orden, stærkest manifesteret i forbindelse med interventionerne i Kosovo i 1999 og i Irak i 2003. Efterspørgslen efter fredsskabelse øgedes med ophævelsen af supermagtkonfliktens overlejring af nationale og regionale konfliktmønstre, og de mindre lande forventedes at bidrage til arbejdet, også militært. Og med kun én supermagt tilbage gav det ikke længere mening at se Norden som en tredje vej mellem $\varnothing_{\text {st og }}$ Vest. Det betød, at aktivismen måtte gentænkes, selv om målene grundlæggende var de samme og oven i købet i 1990 blev ekspliciteret i den såkaldte 'aktive internationalisme', der blev retningsgivende for de følgende år: at fremme fælles sikkerhed, sikre demokrati og menneskerettigheder, skabe global økonomisk og social udvikling og sikre økologisk bæredygtig udvikling (Udenrigsministeriet 1990). Den danske aktivisme rummede derfor også en ofte overset styrkelse af nordisk aktivisme, idet det var ideer og værdier centrale for den nordiske aktivisme, der blev videreført med delvist nye midler og et delvis skift i foretrukne samarbejdspartnere. Trods et voldsomt fokus på den militære aktivisme og samarbejdet med USA, så fortsatte Danmark som et af de få lande, der levede op til FN's krav om at give mindst $0,7 \%$ af BNP i statslig udviklingsbistand (endda med en stigende andel i de første år efter den Kolde Krig), og dansk medlemskab af FN's sikkerhedsråd i 2005-2006 blev i høj grad sikret via Danmarks netværk i den tredje verden og det fortsat stærke renommé i FN-systemet. Samtidig var en central dansk prioritet i 1990erne og i starten af 00erne udvidelserne af EU og NATO. Ideen bag disse projekter var at styrke institutionaliseringen af Danmarks nærområde, og derfor var det, ikke overraskende de baltiske landes ansøgninger, som Danmark i særlig grad valgte at støtte. Realismen og idealismen gik 'i spand', som anbefalet af Hækkerup mere end 30 år tidligere.

Det var imidlertid klart, at den samme udvikling ikke havde fundet sted i de øvrige nordiske lande, og at Danmark gradvist gled længere væk fra de andre. Nabo- 
erne i Norden stod stadig højt på Danmarks liste, når det gjaldt, hvilke lande man helst samarbejdede med i internationale aktioner på eksempelvis Balkan (Jakobsen 2006: 95). Men både hvad angår hyppigheden og styrken med hvilken Danmark valgte at engagere sig i internationale aktioner, var der tale om et skred i forhold til de nordiske naboer (Wivel 2014). Dette cementeredes igennem 1990erne, hvor man påbegyndte en langt mere vidtgående omstrukturering af det danske forsvar, end det var tilfældet i de øvrige nordiske lande. Væk fra territorialforsvaret og hen imod en mindre, professionel hær, der med kort varsel kunne deltage i internationale operationer (Jakobsen 2006: 99-103). Dette kunne lade sig gøre, fordi man i Danmark, for første gang i flere hundrede år, følte sig fri fra en direkte trussel mod sin eksistens (Forsvarskommissionen 1998), og derfor hurtigt kunne lede ressourcer fra regionale opgaver over i kapaciteter med et mere globalt sigte. Dette stod i modsætning til Norge, som i langt længere tid holdt fast i det regionale og snarere forsøgte at inkorporere det globale som en „ekstra“ opgave for det norske forsvar (Græger og Leira 2005: 53-54).

Denne tendens blev yderligere styrket i 00erne, hvor særligt båndet til USA blev bekræftet gennem deltagelse i den amerikanske „Krig mod terror“. Det førte til relativt tunge og risikovillige danske bidrag til krigen i Afghanistan sammenlignet med de øvrige nordiske lande. Det samme gjorde sig i endnu højere grad gældende i forhold til Danmarks bidrag til krigen i Irak, hvor Sverige, til sammenligning, helt afstod fra at deltage, og Norge først sent besluttede sig til at deltage med en mindre styrke. ${ }^{3}$ Irakkrigen skabte imidlertid også modreaktioner internt i Danmark, idet den danske krigsindsats for første gang ikke havde opbakning fra det største oppositionsparti, Socialdemokraterne. Og selvom partiet senere hen valgte at støtte politisk op om dansk deltagelse til en stabiliseringsstyrke i 2004, så fortrød partiet efterfølgende den beslutning, og tilsluttede sig fra 2007 bestræbelser for at nedsætte en kommission til undersøgelse af den danske beslutning om at deltage i krigen i Irak (FT 2008). Uenighed om deltagelsen i krigen i Irak var ikke kun et dansk eller et nordisk fænomen. Overalt i Europa var Irak-krigen heftigt debatteret. Men i Danmark skabte det i særlig grad indre dissonans at gå i krig for, hvad man anså for danske og nordiske normer om demokrati og menneskerettigheder, men i en kontekst uden klart FNmandat, hvilket implicit kunne tolkes som en svækkelse af FN og dermed af det internationale samfunds institutionalisering. Samtidig betonede regeringen i sin argumentation for dansk deltagelse klassiske nordiske værdier som menneskerettigheder og demokrati i tillæg til - og ofte i højere grad end - de sikkerhedspolitiske argumenter, som var afgørende i eksempelvis USA og Storbritannien (ligesom man i forbindelse med indsatsen i Afghanistan betonede eksempelvis kvinders rettigheder). Dilemmaet var dermed beslægtet med Kosovointerventionen i 1999, men blev forværret af, at man ikke som i 1999 kunne henvise til den russiske vetoret i sikkerhedsrådet, da en ny FN-resolution efter alt at dømme ikke kunne have opnået majoritet (Petersen 2004: 587). Mens dansk deltagelse i Kosovointerventionen således kunne forklares som et valg mellem idealpolitik og realpolitik, hvor Danmark i overensstemmelse med den klassiske nordiske aktivisme valgte idealerne og gik imod de russiske realpolitikere, så præsenterede Irak sig som et mere klart dilemma mellem centrale værdier og en diskussion om, hvilke redskaber der var legitime og nødvendige for at fremme disse. Netop af den grund er det næppe tilfældigt, at krigen i Irak foranledigede den hidtil største divergens i den nordiske aktivisme fra land til land i Norden.

Irak forblev dog undtagelsen i en ellers stærk dansk konsensus om aktivismen. Samtidig begyndte de andre nordiske lande med Norge i spidsen at rykke sig gradvist nærmere den danske linje. Det resulterede bl.a. i en stærk nordisk deltagelse i krigen mod Gadaffiregimet i Libyen i 2011, hvor danske og norske fly stod for en usædvanlig stor andel af koalitionens bombetogter (Jakobsen og Møller 2012). Og også på anden vis betød afslutningen af 00erne en gradvis tilnærmelse mellem de nordiske lande. Delvist ansporet af behovet for besparelser på forsvaret i kølvandet på finanskrisen bragte tidligere norsk forsvarsminister og udenrigsminister Thorvald Stoltenberg i 2009 det nordiske tilbage på dagsordenen med sin rapport for Nordisk Ministerråd Nordic Cooperation on Foreign and Security Policy (Stoltenberg 2009), der pegede på en række konkrete samarbejdsområder i udenrigs- og sikkerhedspolitikken for de nordiske lande. Mens det var sigende, at rapporten vakte betydeligt mindre politisk og offentlig debat i Danmark end $i$ andre nordiske lande, og tydeligt at de danske udenrigspolitiske beslutningstagere ikke ønskede at forpligte sig på rapportens anbefalinger (Archer 2010), så var dens konklusioner retningsgivende for en udvikling, der i 2009 førte til oprettelsen af NORDEFCO som en fleksibel platform for militært samarbejde de nordiske lande, herunder Danmark, imellem. En 'integration à la carte' (Saxi 2011: 19), der som påpeget af Tuomas Forsberg er mulig 'because it is not seen as an alternative to cooperation within the EU or NATO' (Forsberg 2013: 1175), men derimod et pragmatisk samarbejde som de nordiske lande kan koble ind i, når samarbejdet gennem NATO og EU bliver for tungt, og som ydermere placerer sig solidt indenfor både EU's og NATO's diskurs om mere sikkerhed for de samme penge (Wivel og Marcussen 2015). 
På trods af denne udvikling og på trods af de fortsat stærke nordiske karakteristika i den danske udenrigspolitiske aktivisme, så er det nordiske samarbejde forblevet i periferien af dansk udenrigs- og sikkerhedspolitik. Spørgsmålet er på den baggrund, hvorvidt og i givet fald hvordan den seneste udvikling i Danmarks - og Nordens - nærområde vil styrke den nordiske dimension i dansk udenrigspolitik?

\section{En fremtid for den nordiske aktivisme i dansk udenrigspolitik?}

Hvilken rolle vil den nordiske aktivisme fremadrettet spille i dansk udenrigspolitik? To områder synes oplagte for nordisk samarbejde. Ukrainekonflikten mellem Rusland og Vesten har mindet om, at den europæiske fred og institutionalisering, som har udgjort et stadig stærkere fundament for politik i regionen gennem de seneste årtier, fortsat hviler på en række særlige geopolitiske betingelser, som vi ikke kan tage for givet vil vare ved, og som vi ikke nødvendigvis har de rette redskaber til at bevare. På den baggrund publicerede de fem nordiske forsvarsministre i april 2015 en fælles kronik i den norske avis Aftenposten, som bl.a. tager afstand fra Ruslands krænkelser af de nordiske landes luftrum. Alene det faktum, at de fem nordiske ministre formåedes at enes om så relativt uforbeholden kritik af Rusland, understreger, at de nordiske landes forhold til Rusland har undergået store forandringer. Også selv om ministrene, når det gæl-

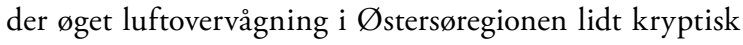
henviser til en voldsspiral i 'øst', der giver behov for øget samarbejde i de nordiske landes 'nærområde' frem for her at nævne Rusland direkte. ${ }^{4}$

Det indikerer, at når det gælder konkrete fællesnordiske tiltag rettet mod Rusland, så skal udtalelsen stadig være meget forsigtig, før alle fem nordiske forsvarsministre kan sætte deres navne under. Endelig lægger kronikken også vægt på solidaritet overfor regionens naboer i Baltikum, et klassisk nordisk emne, og der lægges op til øget samarbejde, når det pragmatisk giver mening, $\mathrm{i}$ internationale operationer. Om erklæringen primært skal ses retorisk, er endnu et åbent spørgsmål. Nordisk samarbejde som ide har bevaret en folkelige appel - ingen bliver vrede når de politiske beslutningstagere siger noget pænt om vores fællesnordiske værdier og mulighederne for at samarbejde med udgangspunkt i disse - men traditionelt har større strategiske hensyn spændt ben for samarbejdet. I NORDEFCO har man tilsyneladende taget ved lære af denne fortid. Det har netop gjort det muligt at fokusere samarbejdet på de områder, der giver mening for hver enkelt af de fem nordiske lande. Således tillader NORDEFCO de enkelte lande tilvalg og fravalg af specifikke samarbejdsemner. NORDEFCO's indledende succes synes derfor at understrege, at det nordiske samarbejde netop har det bedst, når det indrettes med pragmatisme i højsædet. Det gælder ikke mindst i en dansk kontekst, hvor netop en pragmatisk aktivistisk tilgang til internationale institutioner har været kendetegnende for dansk udenrigspolitik både under og efter den Kolde Krig (Wivel 2013).

Et andet oplagt område for øget nordisk samarbejde er i forbindelse med den arktiske region. Her er alle fem nordiske lande fuldgyldige medlemmer af Arktisk Råd, regionens centrale forum for samarbejde staterne imellem. Selvom der stadig findes enkelte mindre uoverensstemmelser imellem de nordiske lande indbyrdes og med Canada, så er udfordringen, også i Arktis, specielt for Danmark centreret omkring at finde en løsning med Rusland om tilbageværende konflikter over kontinentalsoklen under det Arktiske Ocean. Arktis har i mange år haft status af lavspændingsområde. Det skyldes især, at Rusland, mere eller mindre, har afholdt sig fra store aggressive fremstød, og fordi netop Rusland har en stor interesse i regionens stabilitet. Netop stabilitet er nemlig en forudsætning for, at Rusland for alvor kan begynde at udvinde de ressourcer, der måtte findes i de store arktiske områder, som de allerede besidder retten til (Olesen 2014: 9-11). Spørgsmålet er nu, hvordan Ukrainekonflikten vil påvirke situationen i Arktis i det lange løb. Skulle samarbejdet i Arktis vise sig at have taget varig skade, kan øget nordisk samarbejde om bl.a. overvågning og patruljering, i parløb med USA og Canada, vise sig at blive nødvendigt.

En tilbagevenden til nordisk aktivisme som den så ud under den Kolde Krig ligger næppe i kortene, ikke mindst fordi det er særdeles tvivlsomt, om Rusland vil have styrke til at genstarte den Kolde Krig som en ligeværdig modpol til USA og Vesten indenfor en overskuelig årrække. Dermed virker det mere sandsynligt, at øget russisk pres, snarere end at afskrække Sverige og Finland fra øget samarbejde med de nordiske NATO-medlemmer, vil bringe landene tættere sammen og Sverige og Finland tættere på NATO. Det gør mulighederne for nordisk samarbejde i Østersøregionen bedre end det har været i mange år. På samme baggrund burde nordisk normfremme i FN have gode muligheder.

På disse områder burde der således være ganske gode forudsætninger for, at nordisk aktivisme, så forskelligt praktiseret af hvert af de nordiske lande i 00'erne, igen kan blive et fælles nordisk projekt.

Derimod vil der, fraregnet dansk-norsk samarbejde indenfor NATO, ligge flere udfordringer $i$ en udvidelse af det direkte samarbejde i internationale operationer særligt i operationer med en „hård“ militær komponent. Ikke alene vil institutionsskellet - med Sverige og Finland 
udenfor NATO, og Island, Norge og Danmark (grundet det danske forbehold) militært udenfor EU - være i vejen for sådanne planer. Men hertil kommer, at især det danske militær, efter en årrække med internationale operationer med amerikanerne, briterne og, til dels, franskmændene, efterhånden har kapaciteter skræddersyet til samarbejde med netop disse lande (Jakobsen and Møller 2012: 113).

\section{Konklusion}

Den nordiske dimension har spillet en væsentlig men ofte implicit rolle i udviklingen af dansk udenrigspolitisk aktivisme gennem de seneste årtier. Særligt når det gælder de udenrigspolitiske mål er afspejlingen af traditionel nordisk aktivisme tydelig, men selv når det gælder anvendelsen af de militære midler, som har spillet en afgørende rolle i forfølgelsen af disse mål, kan der trækkes linjer tilbage til den klassiske nordiske koldkrigs-aktivisme. På den baggrund kan den aktuelle udformning af dansk udenrigspolitisk aktivisme tolkes som en videreførelse af koldkrigs-aktivismen under nye geopolitiske rammebetingelser.

Samtidig har den nordiske dimension gennem de seneste årtier spillet en mindre eksplicit rolle i udenrigspolitikken og dens legitimering end det tidligere var tilfældet, både indadtil overfor den danske befolkning og udadtil i forhold til toneangivende internationale aktører. Det skyldes, at ekspliciteringen af den nordiske dimension var særlig effektiv som udenrigspolitisk instrument under den Kolde Krig, hvor italesættelsen af Norden som en særligt fredelig og progressiv region tjente som en nordisk 'bastion', der beskyttede regionen mod stormagtsdominans gennem aktivering af begreber som den nordiske balance og den nordiske model (Mouritzen 1995). Denne platform mistede sin betydning for dansk udenrigspolitik med Sovjetunionens sammenbrud og bortfaldet af den supermagtskonfrontation, som modellen stod i kontrast til. Det førte umiddelbart til større divergens mellem Danmark og de øvrige nordiske lande i de første årtier efter den Kolde Krig, fordi Danmark i langt højere grad end de andre søgte nye veje for aktivismen gennem det tættere samarbejde med USA og Storbritannien - en udenrigspolitik som på mange måder bedst kan beskrives som nordisk aktivisme med nye midler.

Med de senere års udvikling i russisk udenrigspolitik kombineret med de stadigt øgede krav til effektiv ressourceanvendelse i udenrigs- og sikkerhedspolitikken har det nordiske samarbejde fået ny aktualitet for dansk udenrigspolitik. Med sin pragmatiske drejning siden den Kolde Krigs afslutning og nedtoningen af Norden som værdipolitisk alternativ er den nordiske aktivisme mindre distinkt end tidligere. Og med skredet i de andre nordiske lande $\mathrm{i}$ retning af mere villighed til at deltage $\mathrm{i}$ amerikansk ledede internationale interventioner er nordisk aktivisme samtidig mere dansk end nogensinde. Både som implicit retningsgiver og som eksplicit ramme for aktuel problemløsning synes den nordiske dimension i dansk udenrigspolitik således at fortsætte, eller måske endog styrke, sin betydning for dansk udenrigspolitisk aktivisme i de kommende år.

\section{Litteraturliste}

Andrén, Nils (1967) 'Nordic Integration', Cooperation and Conflict 2(1): $1-25$.

Archer, Clive (2010) 'The Stoltenberg Report and Nordic Security: Big Idea, Small Steps', i N. Hvidt and H. Mouritzen (eds) Danish Foreign Policy Yearbook 2010, Copenhagen: Danish Institute for International Studies: 43-74.

Björkdahl, A. (2008) 'Norm Advocacy: a small state strategy to influence the EU', Journal of European Public Policy 15(1): 135-154.

Branner, Hans (2000) 'Options and Goal in Danish European Policy since 1945: Explaining Small State Behavior and Foreign Policy Change', i Hans Branner and Morten Kelstrup (red.) Denmark's Policy Towards Europe after 1945: History, Theory and Options,. Odense: Odense University Press: 333-380.

Brundtland, Arne Olav (1967) 'The Nordic Balance Past and Present', Cooperation and Conflict 2(2): 30-63.

Browning, Christopher (2007) 'Branding Nordicity: Models, Identity, and the Decline of Exceptionalism', Cooperation and Conflict 42(1): $27-51$.

Dahl, Ann-Sofie and Pauli Järvenpää (2014) (red.) Northern Security and Global Politics: Nordic-Baltic strategic influence in a post-unipolar world, London: Routledge.

Forsberg, Tuomas (2013) 'The rise of Nordic defence cooperation: a return to regionalism?', International Affairs 89(5): 1161-1181.

Forsvarskommissionen af 1997 (1988) Fremtidens Forsvar, Hovedbind. Copenhagen: Schultz Grafisk.

FT (2014a), B 122: Forslag til folketingsbeslutning om dansk militært bidrag til støtte for indsatsen i Irak, 1. behandling, http://www. ft.dk/samling/20131/beslutningsforslag/B122/BEH1-102/forhandling.htm\#dok (tilgået 15. maj 2015)

FT (2014b), B 123: Forslag til folketingsbeslutning om yderligere dansk militært bidrag til støtte for indsatsen mod ISIL, 1. behandling, http://www.ft.dk/samling/20131/beslutningsforslag/B123/BEH1107/forhandling.htm\#dok (tilgået 15. maj 2015)

FT (2008), B 18: Forslag til folketingsbeslutning om nedsættelse af en kommission til undersøgelse af regeringens tilslutning til og deltagelse i den internationale koalition til afvæbning af Irak, 1. behandling, http://www.ft.dk/samling/20072/beslutningsforslag/ b18/beh1-40/forhandling.htm?startItem=-1\#alleindlaeg (tilgået 30 . Juli 2015)

Goetschel, Laurent (2013) 'Bound to be peaceful? The changing approach of Western European small states to peace', Swiss Political Science Review 19(3): 259-278.

Græger, Nina og Halvard Leira (2005) 'Norwegian Strategic Culture after World War II From a Local to a Global Perspective', Cooperation and Conflict 40(1): 45-66.

Grøn, Caroline, Peter Nedergaard og Anders Wivel (red.) (2015) The Nordic Countries and the European Union: Still The Other European Community?, London: Routledge. 
Hey, Jeanne A. K. (2003) 'Introduction: Small State Foreign Policy', i Jeanne A. K. Hey (red.) Small States in World Politics: Explaining Foreign Policy Behaviour, Boulder: Lynne Rienner: 1-11.

Helveg, Niels (1999) 'Folkeret i en brydningstid', Politiken, 25. juni

Holm, Hans-Henrik (1997) 'Denmark's Active Internationalism: Advocating International Norms with Domestic Constraints', i Bertel Heurlin og Hans Mourtizen (red.) Danish Foreign Policy Yearbook 1997, København: Dansk Udenrigspolitisk Institut: 52-80.

Holm, Hans-Henrik (2002) 'Danish Foreign Policy Activism: The Rise and Decline, i Bertel Heurlin og Hans Mouritzen (red.) Danish Foreign Policy Yearbook 2002, København: Dansk Institut for Internationale Studier: 19-45.

Hækkerup, Per (1965) Danmarks udenrigspolitik. Copenhagen: Fremad. Ingebritsen, Christine (2002) 'Norm Entrepreneurs: Scandinavia's Role in World Politics', Cooperation and Conflict 37(1): 11-23.

Jakobsen, Peter Viggo (2006). Nordic Approaches to Peace Operations: A New Model in the Making? Abingdon: Routledge.

Jakobsen, Peter Viggo (2009) 'Small States, Big Influence: The Overlooked Nordic Influence on the Civilian ESDP', Journal of Common Market Studies 47(1): 81-102.

Jakobsen, Peter Viggo (2015) 'Danmarks militære aktivisme fortsætter med eller uden USA', Politik 18(4).

Jakobsen, Peter Viggo and Karsten Møller (2012) 'Good News: Libya and the Danish Way of War', i Nanna Hvidt og Hans Mouritzen (red.) Danish Foreign Policy Yearbook 2012, København: Dansk Institut for Internationale Studier: 106-130.

Keohane, Robert O. (1969) 'Lilliputians' Dilemmas: Small States in International Politics', International Organization 23(2): 291-310.

Laatikainen, Katie Verlin (2003) 'Norden's Eclipse: The Impact of the EUs Common Foreign and Security Policy on Nordic Cooperation in the United Nations', Cooperation and Conflict 38(4): 409-441.

Lidegaard, Bo (2003) Overleveren, København: Gyldendal.

Mouritzen, Hans (1995) 'The Nordic Model as a Foreign Policy Instrument: Its Rise and Fall', Journal of Peace Research 32(1): 9-21.

Mouritzen, Hans (2007) 'Denmark's super Atlanticism', Journal of Transatlantic Studies 5(2): 155-167.

Neumann, I.B. and Gstöhl S. (2006) 'Introduction: Lilliputians in Gulliver's World?', I Christine Ingebritsen, Iver B. Neumann, Sieglinde Gstöhl og Jessica Beyer (red.) Small States in International Relations, Seattle: University of Washington Press: 3-36.

Olesen, Thorsten B., and Poul Villaume (2005). I Blokopdelingens Tegn 1945-1972. Dansk Udenrigspolitiks Historie bn. 5, København: Danmarks Nationalleksikon.

Olesen, Mikkel Runge (2014) 'Cooperation or conflict in the Arctic: A Literature Review', Working Paper, København: DIIS

Panke, Diana (2010) 'Good Instructions in No Time? Domestic Coordination of EU Policies in 19 Small States', West European Politics 33(4): 770-790.

Pedersen, Rasmus Brun (2012) 'Fra aktiv internationalisme til international aktivisme: Udvikling og tendenser i dansk udenrigspolitisk aktivisme', Politica 44(1): 111-130.

Pedersen, Ole Karup (1970) Udenrigsminister P. Munchs opfattelse af Danmarks stilling i international politik, København: Københavns Universitet.

Petersen, Nikolaj (1983) 'Danmark: Dansk afspændingspolitik i 1980erne' I Bertel Heurlin (red.), Norden og den internationale spanding, København: Forlaget Politiske Studier: 75-89.

Petersen, Nikolaj (2004). Europaisk Og Globalt Engagement. Dansk Udenrigspolitiks Historie bn. 6, København: Danmarks nationalleksikon.
Rasmussen, Mikkel Vedby (2005) 'What's the Use of It? Danish Strategic Culture and the Utility of Armed Forces', Cooperation \& Conflict 40(1): 67-89.

Ringsmose, Jens (2009) 'Paying for Protection: Denmark's Military Expenditure during the Cold War', Cooperation and Conflict 44(1): 73-97.

Ringsmose, Jens og Sten Ryning (2008) 'The impeccable Ally? Denmark, NATO, and the Uncertain Future of Top Tier Membership', i Nanna Hvidt og Hans Mouritzen (red.) Danish Foreign Policy Yearbook 2008. København: Dansk Institut for Internationale Studier: 55-84.

Saxi, Håkon Lunde (2011) Nordic Defence Cooperation after the Cold War, Oslo Files on defence and Security 1/2011, Oslo: Norwegian Institute for Defence Studies.

Schouenborg, Laust (2013a) The Scandinavian International Society: Primary institutions and binding forces, 1815-2010, Routledge: London.

Schouenborg, Laust (2013b) 'Nordisk diplomati: I det skandinaviske internationale samfunds tjeneste?', Samfundskøkonomen, No. 2, 2013: $18-24$

Simonyi, András (2013) “"Nordic Cool Power in Washington": What the Nordics Teach About Nation Branding', The World Post, http:// www.huffingtonpost.com/andras-simonyi/nordic-cool-power-inwasi_b_2748954.html

Stoltenberg, Thorvald (2009) Nordic Cooperation on Foreign and Security Policy, Proposals presented to the extraordinary meeting of Nordic foreign ministers in Oslo on 9 February 2009 https://www. regjeringen.no/globalassets/upload/ud/vedlegg/nordicreport.pdf (tilgået 12. Maj 2015).

Udenrigsministeriet (1990) Udenrigstjenesten mod år 2000, København: Udenrigsministeriet.

Udenrigsministeriet (2003) En verden i forandring. Regeringens bud på nye prioriteter i Danmarks udenrigspolitik. København: Udenrigsministeriet.

Ugens Gallup (1956), Danmark og Skandinavian I: Det skandinaviske samarbejde, http://www2.tns-gallup.dk/tns_gallup/ugens_gallup/ tekst/ug_1956_36.pdf (tilgået 18. april 2015)

Ugens Gallup (1967), Danmark mellem NORDEK og EEC. http:// www2.tns-gallup.dk/tns_gallup/ugens_gallup/tekst/ug_1969_35. pdf (tilgået 21. April 2015)

Ugens Gallup (1991), Norden samlet I EF? http://www2.tns-gallup. dk/tns_gallup/ugens_gallup/tekst/ug_1991_36.pdf (tilgået 21. April 2015)

Villaume, Poul (1995). Allieret med Forbehold - Danmark, Nato og Den Kolde Krig. København: Forlaget Eirene.

Wallace, William (1999) 'Small European States and European PolicyMaking: Strategies, Roles, Possibilities', i William Wallace et al. Between Autonomy and Influence: Small States and the European Union, Arena Report No. 1/99, Oslo: Arena: 11-26.

Wivel, Anders (2005) 'Between Paradise and Power: Denmark's Transatlantic Dilemma', Security Dialogue 36(3): 417-421.

Wivel, Anders (2013) 'From Peacemaker to Warmonger? Explaining Denmark's Great Power Politics', Swiss Political Science Review 19(3): 298-312

Wivel, Anders (2014) 'Birds of a feather flying apart? Explaining Nordic dissonance in the (post) unipolar world', i Ann-Sofie Dahl and Pauli Järvenpää (eds) Northern Security and Global Politics: Nordic-Baltic strategic influence in a post-unipolar world, London: Routledge: 7992

Wivel, Anders og Martin Marcussen (2015) 'In the shadow of history? Explaining the (lack of) Europeanisation of Nordic security and defence policies', i Caroline Grøn, Peter Nedergaard og Anders Wi- 
vel (red.) The Nordic Countries and the European Union, London: Routledge: 206-225

Wæver, Ole (1992) 'Nordic nostalgia: Northern Europe after the Cold War', International Affairs 68(1): 77-102.

\section{Noter}

1. Mikkel Runge Olesens del af arbejdet med artiklen er finansieret af Dansk Institut for Internationale Studiers program for Forsvars- og Sikkerhedspolitiske studier.
2. For en generel diskussion af aktivismebegrebet og dets anvendelse på dansk udenrigspolitik, se introduktionsartiklen til dette temanummer.

3. Finlands og Islands involvering i de to konflikter var meget begrænset.

4. http://www.aftenposten.no/meninger/kronikker/Fem-nordiskeministre-i-felles-kronikk-Russisk-propaganda-bidrar-til-a-sasplid-7967230.html (Tilgået 20. april 2015). 